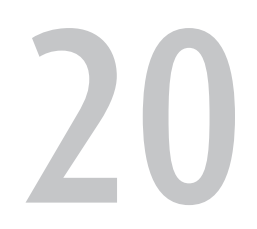

\title{
Post-fire experimental trials of vegetation restoration techniques in the peatlands of Namadgi (ACT) and Kosciuszko National Parks (NSW), Australia
}

\section{Jennie Whinam}

Biodiversity Conservation Branch, Department of Primary Industries, Parks, Water and Environment, Hobart Tasmania, Australia

Jennie.Whinam@dpipwe.tas.gov.au

\section{Geoffrey Hope}

Archaeology and Natural History, Australian National University, Canberra, Australia

\section{Roger Good}

Research Associate, Australian National Botanic Gardens

\section{Genevieve Wright}

NSW Parks and Wildlife Service, Department of Climate Change, Queanbeyan, Nsw, Australia

\section{Introduction}

In January 2003, wildfires, ignited by lightning strikes, burnt approximately 2.1 million ha in the ACT, NSW and Victoria. These wildfires burnt a high proportion of subalpine peatlands, (both Sphagnum-shrub bog and sedge fens) across the Snowy Mountains, in New South Wales and in the Brindabella Ranges, in the ACT. These communities are widely distributed and cover about 5500 ha in the alpine and subalpine zones of Kosciuszko National Park, but are of limited area and occurrence in Namadgi National Park, where they total 320 ha. The bogs and fens occur above approximately $1000 \mathrm{~m}$ altitude at the heads of streams and along stream floodplains where annual precipitation is greater than $850 \mathrm{~mm}$ and mean annual temperatures below $12^{\circ} \mathrm{C}$ (Hope 2003).

As Sphagnum and its underlying peats are known to be fire-sensitive (Good 2000; Whinam and Chilcott 2002; Walsh and McDougall 2004), there was considerable concern about the 
long-term impacts of the fires on the bog and fen ecosystems. This concern, coupled with observation of active peat tunnelling and incision, as well as erosion of natural peat 'dams' in streams, prompted a program to monitor the recovery of the vegetation communities and to trial several techniques to initiate and enhance bog and fen vegetation recovery at selected bogs in Kosciuszko National Park and Namadgi National Park (Figure 1).

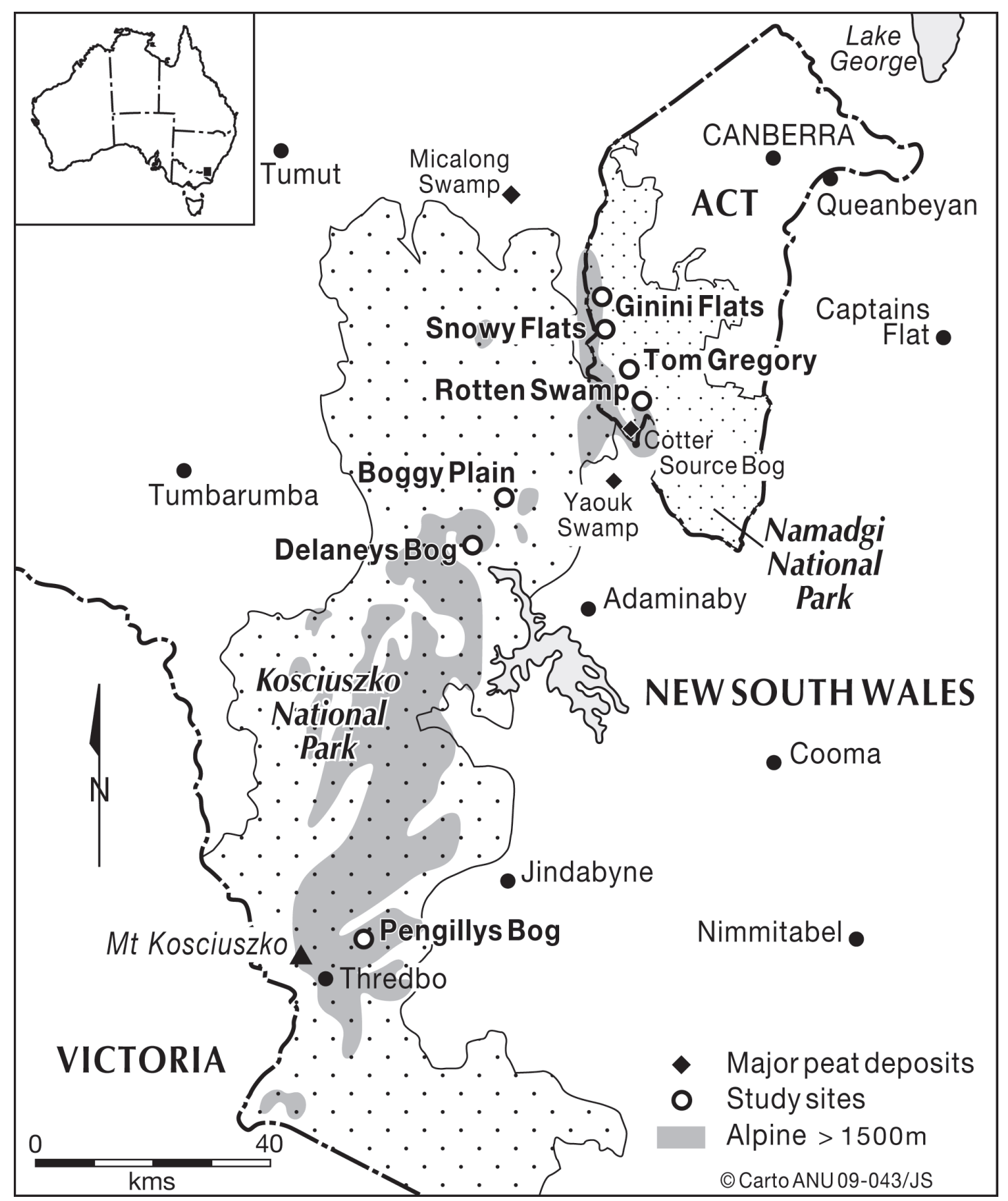

Figure 1. Location of sites mentioned in the text

The peatlands that burnt are an important functional component of the water supply to Canberra and to the Snowy Mountains Hydroelectric Scheme as they retain sediment and solutes and moderate flow discharges. The higher altitude sites also act as snow accumulation sites in winter, with the snow thawing in spring and saturating the underlying peatbeds. Most of these peatlands were recovering gradually from the effects of grazing that ended more than 50 years ago (Costin et al 1959; Wimbush and Costin 1979; Good 1992, 2000), 
but the January 2003 fires reversed these gains. The few long-term studies of bog recovery trends in Australia have shown that recovery after fires and grazing takes decades (Carr and Turner 1959; Wahren et al. 1996; Wahren and Walsh 2000). Sphagnum-shrub bog-with-pool complexes are very slow to recover from disturbance (Ashton and Hargreaves 1993; Good 2000; Whinam and Chilcott 2002; Whinam et al. 2003). Although Sphagnum can grow rapidly in favourable circumstances, most undisturbed bogs are currently only accumulating organic matter slowly, or may be oxidising with net loss of bulk and carbon (Clark 1980; Clarke and Martin 1999).

Post fire, while the vegetation in the montane peatlands had been severely damaged, most underlying peat surfaces were scorched by the fires but remained intact. Residual moisture in the peat prevented burning of the peat except along channel edges and other dry sites. In these sites, peat burnt to depths of 5-20 cm, leaving sterile ash surfaces with a $\mathrm{pH} 6$, leading to increased weed invasion, frost heave and peat and flowline erosion.

The Sphagnum mires of the Australian Alps are at the climatic limit for these peatlands (Whinam et al. 2003). Evapotranspiration in the hottest month is the limiting factor for the distribution of Australian Sphagnum peatlands (Whinam et al. 2003). Up to 70\% natural shading by shrubs has been shown to favour Sphagnum moss growth (Whinam 1990; Whinam and Buxton 1997). A combination of reseeding with moss and the application of small amounts of low phosphorous fertiliser have been shown to improve recovery rates after Sphagnum moss harvesting (Rochefort et al. 2003; Cobbaert et al. 2004) and as a strategy in post-grazing alpine rehabilitation works (Good 1976, 1992, 2000).

The results after four years of trials of vegetation recovery techniques and post-fire monitoring of the peatland vegetation in selected sites in Namadgi and Kosciuszko National Parks are presented here (Figure 1, Table 1). Experimental treatments include (a) different types of shading, (b) addition of fertiliser, and (c) transplants of Sphagnum moss. The aim of these trials is to assess additional peatland revegetation techniques which can be incorporated into the extensive restoration and rehabilitation program underway in Namadgi and Kosciuszko National Parks. The restoration program is attempting to restore and rehabilitate the hydrological functioning of these disturbed peatlands (Hope et al. 2005; Good et al. In press). The results of these trials may help guide future peatland restoration and management across the Alps.

Table 1. Sites for post-fire regeneration plots

\begin{tabular}{|c|c|c|c|c|}
\hline Site Name & Locality & State & Altitude m & Lat Long \\
\hline Boggy Plain & Northern Kosciuszko NP & NSW & 1370 & $35^{\circ} 52.7^{\prime} \mathrm{S}, 148^{\circ} 36.0^{\prime} \mathrm{E}$ \\
\hline Delaneys Bog & Northern Kosciuszko NP & NSW & 1480 & $35^{\circ} 54.5^{\prime} \mathrm{S}, 148^{\circ} 33.7^{\prime} \mathrm{E}$ \\
\hline Ginini Bog & Mt Ginini, Namadgi NP & ACT & 1590 & $35^{\circ} 31.1^{\prime} \mathrm{S}, 148^{\circ} 46.3^{\prime} \mathrm{E}$ \\
\hline Pengillys Bog & Central Kosciuszko NP & NSW & 1680 & $36^{\circ} 22.8^{\prime} \mathrm{S}, 148^{\circ} 24.8^{\prime} \mathrm{E}$ \\
\hline Rotten Swamp & Mt Kelly, Namadgi NP & $\mathrm{ACT}$ & 1445 & $35^{\circ} 42.3^{\prime} \mathrm{S}, 148^{\circ} 53.2^{\prime} \mathrm{E}$ \\
\hline Snowy Flat & Mt Gingera, Namadgi NP & ACT & 1618 & $35^{\circ} 33.9^{\prime} \mathrm{S}, 148^{\circ} 51.85^{\prime} \mathrm{E}$ \\
\hline Tom Gregory Bog & Upper Cotter, Namadgi NP & ACT & 1024 & $35^{\circ} 38.9^{\prime} \mathrm{S}, 148^{\circ} 49.8^{\prime} \mathrm{E}$ \\
\hline
\end{tabular}




\section{Methods}

Bogs were visited between February and May 2003 to set up plots and assess the 2003 fire damage. As these sites are also localities for the threatened frog species (corroboree frog Pseudophryne corroboree and alpine tree frog Litorria verreauxii alpina), both of which are sensitive to Chytrid (Batrachochytrium dendrobatiidis) fungal attack (Lintermans and Osborne 2002), all boots and tools were sterilised in bleach before entering each peatland. Care was also taken to avoid the use of zinc-coated products, given the known long-term problems of zinc toxicity in alpine humus soils (Johnston and Good 1996). Fire damage was measured in terms of the degree of preservation of the biomass and peat profile. The categories of damage were identified as (i) unburnt, (ii) burnt but moss cushion intact, (iii) burnt cushion margins, (iv) charred but root mat intact and (v) burnt and incised. Sketch maps of burn classes were made and photo survey points marked with wooden stakes. These are being used to prepare post-fire maps from rectified air photography flown a few weeks after the fires (Nanson and Hope unpubl. data).

\section{Permanent plots}

Permanent plots were established at seven sites (Ginini Bog, Snowy Flat, Tom Gregory Bog and Rotten Swamp in the ACT, and Pengillys Bog, Delaneys Bog and Boggy Plain in Kosciuszko) in April-November 2003 (Figure 1).

The plots sample a range of altitudes (1050-1740 m) in granidiorite catchments, except for Ginini and Tom Gregory bogs, which have shaley metasediment basements. All are located in national parks and catchment areas in which commercial grazing has been excluded for more than 50 years. Some feral stock has been present more recently at some localities (horses at Rotten Swamp and Tom Gregory until 1986 and at Boggy Plain currently). Before the fire, all plots were a mosaic of actively growing Sphagnum-epacrid shrub bog in which scattered areas of Carex and Empodisma fens and Poa tussock-dominated herbland (the Baeckea gunnianaCallistemon pityoides-Sphagnum cristatum wet heathland and subalpine valley grassland communities of MacDougall and Walsh 2007). They were actively grazed by kangaroos, rabbits and rodents such as Mastacomys fuscus. The plots are located in open valley sites on gentle slopes on peats of medium depth (95\% are on 40-125 cm of Sphagnum or humic peat with pH 4-5), subject to both surface-water run-on and runoff. Active streamlines and pools were avoided but waterlogging due to drainage lines varied between quadrat sites. Snow-patch areas were avoided but snow lie varied from a few months at Pengillys to shortlived cover at the other plots.

All plots were damaged severely by the 2003 fire (Table 2) but individual quadrats had variable damage, ranging from being unburnt to quadrats in which the surface peats had been ashed. Almost all quadrats were in damage classes 3 (36\%), 4 (34\%) and $5(26 \%)$, hence had experienced complete death of vegetation above the surface. It is impossible to standardise quadrats from different localities, but similar settings and substrates are intended to allow comparisons for treatments, damage and other factors between plots.

Table 2. Distribution of damage classes by site

\begin{tabular}{|l|l|l|l|l|l|l|l|}
\hline & \multicolumn{7}{|c|}{ Quadrats by damage class by site } \\
\hline Damage class & $\begin{array}{l}\text { Boggy } \\
\text { Plain }\end{array}$ & Delaneys & $\begin{array}{l}\text { Ginini } \\
\text { Bog }\end{array}$ & $\begin{array}{l}\text { Pengillys } \\
\text { Bog }\end{array}$ & $\begin{array}{l}\text { Rotten } \\
\text { Swamp }\end{array}$ & $\begin{array}{l}\text { Snowy } \\
\text { Flat }\end{array}$ & $\begin{array}{l}\text { Tom } \\
\text { Gregory }\end{array}$ \\
\hline 0 & 0 & 0 & 1 & 0 & 0 & 0 & 0 \\
\hline 1 & 2 & 1 & 0 & 1 & 0 & 0 & 0 \\
\hline 2 & 1 & 0 & 0 & 0 & 0 & 2 & 0 \\
\hline 3 & 4 & 4 & 3 & 21 & 7 & 10 & 4 \\
\hline 4 & 2 & 4 & 2 & 29 & 7 & 4 & 1 \\
\hline 5 & 1 & 1 & 4 & 24 & 1 & 4 & 0 \\
\hline Total number of quadrats & 10 & 10 & 10 & 75 & 15 & 20 & 5 \\
\hline
\end{tabular}


At each bog, between five and $75 \times 0.25 \mathrm{~m}^{2}$ quadrats were established and located by fixed stainless-steel pins driven into the basal gravels. This quadrat size has been used in Sphagnum peatlands to monitor natality and mortality rates (Whinam 1995). The quadrats were located in a range of sites with different degrees of fire damage, and sited on hummocks or in hollows. Each plot was assessed for fire damage, surface $\mathrm{pH}$, peat depth and species regeneration. Individual plants were located by $5 \mathrm{~cm}$ squares within the quadrat to allow estimates of survival. Quadrats were remeasured twice a year for five years between 2004 and 2009 for plant cover, floristic diversity, peat accumulation/depth and $\mathrm{pH}$ values.

\section{Fertilisation and transplants}

At Snowy Flat and Pengillys Bog, additional quadrats were set up adjacent to the monitoring plots. Several had fertiliser applications ( $80 \mathrm{~g}$ ) of low-phosphorous, slow-release pellets (Osmocote) to determine whether fertiliser would increase moss growth rates (Whinam and Buxton 1997; Rochefort et al. 2003). In March 2003 at Snowy Flat, transplants of fist-sized plugs of living Sphagnum cushion were placed in some quadrats to test whether they could act as nucleii for future growth, and some received both fertiliser and a transplant. In October-November 2003, larger transplants, approximately $20 \times 20 \times 30 \mathrm{~cm}$, cut with a spade from living Sphagnum and the underlying peat, were placed in holes in shaded hollows at Tom Gregory and Pengillys bogs. These were hand-fertilised with $10 \mathrm{~g}$ of Osmocote at the time of transplant.

\section{Shading}

At Pengillys Bog, three shading treatments were established in burnt and partially burnt peat areas during October 2003, using 70\% shade-cloth material and loosely spread straw (Figure 2, overleaf). Five plots were established, each one including a $20 \mathrm{~m}$ long and $1.6 \mathrm{~m}$ high $70 \%$ shade-cloth fence aligned east-west. Four quadrats were placed on each side of the vertical shade fence and solar radiation levels on northern and southern sides were recorded over the 2004 summer. The effect of shading was compared with a second treatment, in which $15 \mathrm{~m}$ lengths of shade cloth were pegged down horizontally, to lie loosely over the bog surface. A third shade treatment was established using sterilised grass straw spread at a rate equivalent to two tonnes per hectare (70\% cover equivalent).

At Rotten Swamp and Ginini Bog, several lengths of shade cloth were laid out across areas of hummock which were exhibiting a small amount of natural regeneration, to enable subjective comparison with adjacent unshaded areas. At Rotten Swamp, five shaded quadrats can be compared with five unshaded quadrats placed 2-4 $\mathrm{m}$ away from the shade cloth. The shade treatments will demonstrate whether shading has a beneficial effect on recovery and allow us to differentiate between shade alone (vertical shade cloth) and shade with humidity/ evapotranspiration control (mulch and horizontal shade cloth).

\section{Data analysis}

The number of plots and number of quadrats per plot at each site varied, largely due to logistical constraints (Table 3). In general, quadrats were remeasured each autumn and spring from 2003 until spring 2005, and then in autumn 2006 and 2007 (Table 4 and Table 5). At Delaneys Bog, which is immediately adjacent to the Snowy Mountains Highway in the north of Kosciuszko National Park, three of the quadrat markers had disappeared by autumn 2007.

Virtually all quadrats had no, or little, vegetative cover post fire, while some showed little regrowth over the entire period of observations. Even in quadrats where regrowth has occurred, there were taxa that showed little or no recovery in any quadrats. Formal statistical analysis was restricted to the analyses of data from those taxa, families, lifeforms and regeneration types for 


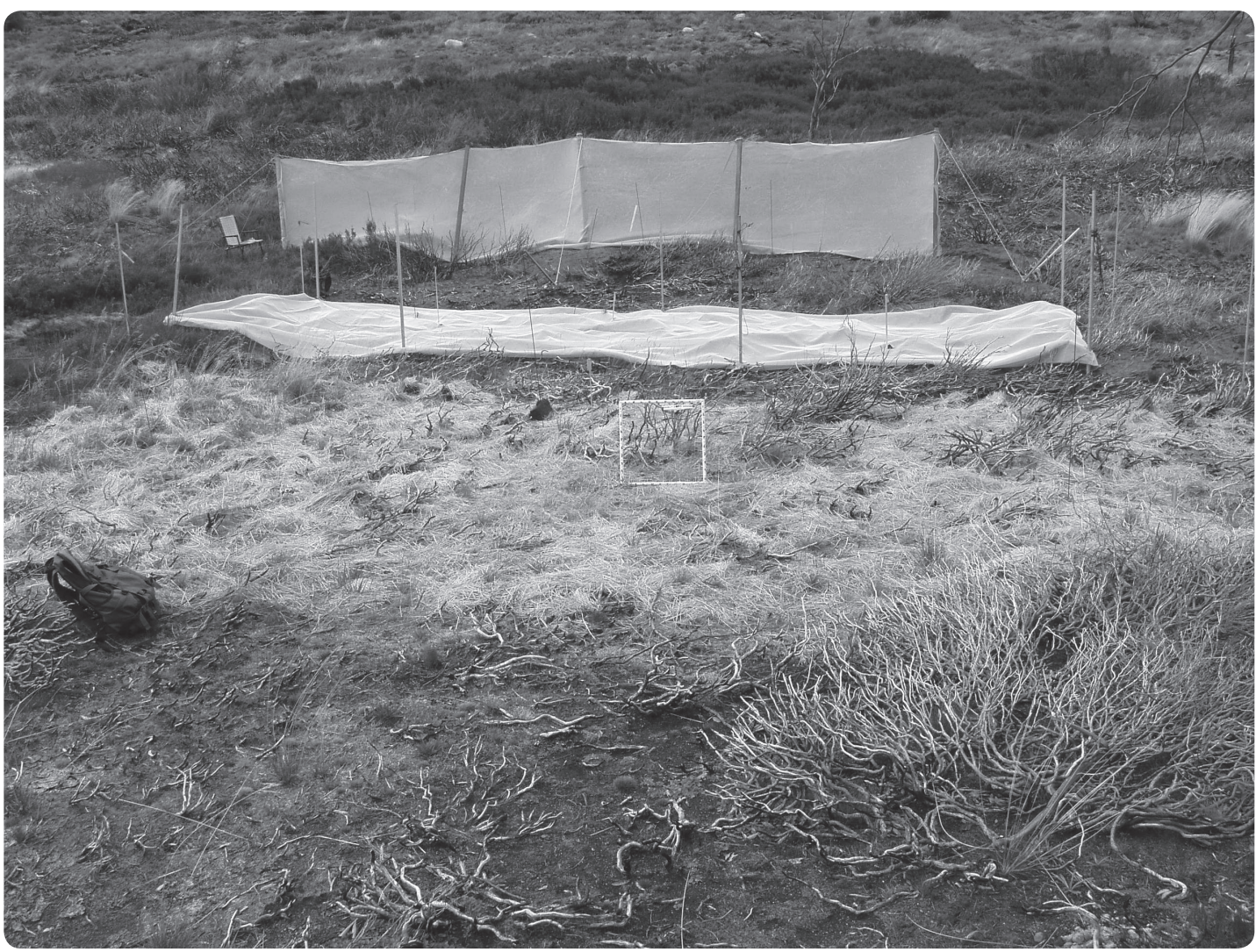

Figure 2. Set up of shade, fertiliser and transplant plots at Pengillys Bog October 2003

Table 3. Number of plots and number of quadrats per plot at each site

\begin{tabular}{|c|c|c|c|c|c|c|c|}
\hline \multirow[b]{2}{*}{ Plot } & \multicolumn{7}{|c|}{ Site } \\
\hline & $\begin{array}{l}\text { Boggy } \\
\text { Plain }\end{array}$ & Delaneys & Ginini Bog & Pengillys Bog & Rotten Swamp & Snowy Flat & Tom Gregory \\
\hline 1 & 1 & 1 & 1 & 14 & 5 & 4 & 1 \\
\hline 2 & 1 & 1 & 1 & 14 & 5 & 4 & 1 \\
\hline 3 & 1 & 1 & 1 & 14 & 5 & 4 & 1 \\
\hline 4 & 1 & 1 & 1 & 14 & & 4 & 1 \\
\hline 5 & 1 & 1 & 1 & 14 & & 4 & 1 \\
\hline 6 & 1 & 1 & 1 & 5 & & & \\
\hline 7 & 1 & 1 & 1 & & & & \\
\hline 8 & 1 & 1 & 1 & & & & \\
\hline 9 & 1 & 1 & 1 & & & & \\
\hline 10 & 1 & 1 & 1 & & & & \\
\hline $\begin{array}{c}\text { Total number } \\
\text { of quadrats }\end{array}$ & 10 & 10 & 10 & 75 & 15 & 20 & 5 \\
\hline
\end{tabular}


Table 4. Number of quadrats at which observations were made in each survey time

\begin{tabular}{|l|l|l|l|l|l|l|l|l|}
\hline & \multicolumn{7}{|c|}{ Site } \\
\hline Year season & $\begin{array}{c}\text { Boggy } \\
\text { Plain }\end{array}$ & Delaneys & Ginini Bog & Pengillys Bog & $\begin{array}{c}\text { Rotten } \\
\text { Swamp }\end{array}$ & Snowy Flat & $\begin{array}{c}\text { Tom } \\
\text { Gregory }\end{array}$ & Total \\
\hline 2003 Autumn & 10 & 10 & 10 & 5 & 5 & 20 & 5 & 65 \\
\hline Spring & & & 10 & 70 & 5 & 20 & 5 & 110 \\
\hline 2004 Autumn & & & 10 & 55 & 15 & 20 & 5 & 105 \\
\hline Spring & & & 10 & 75 & 15 & 20 & 5 & 125 \\
\hline $\mathbf{2 0 0 5}$ Autumn & 10 & 10 & 10 & 55 & 15 & 20 & 5 & 125 \\
\hline Spring & & & 10 & 70 & 15 & 20 & 5 & 120 \\
\hline $\mathbf{2 0 0 6}$ Autumn & & & 10 & 70 & 15 & 20 & 5 & 120 \\
\hline 2007 Autumn & 10 & 7 & 10 & 75 & 15 & 20 & 5 & 142 \\
\hline Total & $\mathbf{3 0}$ & $\mathbf{2 7}$ & $\mathbf{8 0}$ & $\mathbf{4 7 5}$ & $\mathbf{1 0 0}$ & $\mathbf{1 6 0}$ & $\mathbf{4 0}$ & $\mathbf{9 1 2}$ \\
\hline
\end{tabular}

The experimental design of treatments based on combinations of shading, fertiliser and moss transplants is shown in Table 5 .

Table 5. Treatments based on combinations of physical support and regrowth aids employed at different sites, with the number of replications of factor combinations employed at individual sites

\begin{tabular}{|c|c|c|c|c|c|c|c|c|c|}
\hline \multirow[b]{2}{*}{ Regrowth aid } & \multirow[b]{2}{*}{ Cover } & \multicolumn{8}{|c|}{ Site } \\
\hline & & $\begin{array}{c}\text { Boggy } \\
\text { Plain }\end{array}$ & Delaneys & $\begin{array}{c}\text { Ginini } \\
\text { Bog }\end{array}$ & $\begin{array}{c}\text { Pengillys } \\
\text { Bog }\end{array}$ & $\begin{array}{l}\text { Rotten } \\
\text { Swamp }\end{array}$ & $\begin{array}{c}\text { Snowy } \\
\text { Flat }\end{array}$ & $\begin{array}{c}\text { Tom } \\
\text { Gregory }\end{array}$ & Total \\
\hline \multirow[t]{5}{*}{ Fertiliser } & $\begin{array}{l}\text { Horizontal } \\
\text { shade cloth }\end{array}$ & & & & 5 & & & & 5 \\
\hline & Mulch & & & & 5 & & & & 5 \\
\hline & None & & & & & & 5 & & 5 \\
\hline & $\begin{array}{l}\text { Vertical } \\
\text { shade cloth } \\
\text { north side }\end{array}$ & & & & 10 & & & & 10 \\
\hline & $\begin{array}{c}\text { Vertical } \\
\text { shade cloth } \\
\text { south side }\end{array}$ & & & & 10 & & & & 510 \\
\hline \multirow[t]{5}{*}{$\begin{array}{l}\text { Fertiliser and } \\
\text { moss transplant }\end{array}$} & $\begin{array}{l}\text { Horizontal } \\
\text { shade cloth }\end{array}$ & & & & 5 & & & & 5 \\
\hline & Mulch & & & & 5 & & & & 5 \\
\hline & None & & & & & & 5 & & 5 \\
\hline & $\begin{array}{l}\text { Vertical } \\
\text { shade cloth } \\
\text { north side }\end{array}$ & & & & 5 & & & & 5 \\
\hline & $\begin{array}{c}\text { Vertical } \\
\text { shade cloth } \\
\text { south side }\end{array}$ & & & & 5 & & & & 5 \\
\hline Moss transplant & None & & & & & & 5 & & 5 \\
\hline \multirow[t]{5}{*}{ Nil } & $\begin{array}{l}\text { Horizontal } \\
\text { shade cloth }\end{array}$ & & & & 5 & 5 & & & 10 \\
\hline & Mulch & & & & 5 & & & & 5 \\
\hline & None & 10 & 10 & 10 & 5 & 10 & 5 & 5 & 55 \\
\hline & $\begin{array}{c}\text { Vertical } \\
\text { shade cloth } \\
\text { north side }\end{array}$ & & & & 5 & & & & 5 \\
\hline & $\begin{array}{c}\text { Vertical } \\
\text { shade cloth } \\
\text { south side }\end{array}$ & & & & 5 & & & & 5 \\
\hline Grand total & & 10 & 10 & 10 & 75 & 15 & 20 & 5 & 145 \\
\hline
\end{tabular}


which there is at least one time of observation when more than $50 \%$ of observations is greater than zero (G. McPherson, pers comm.). Even with this restriction, it was necessary to group taxa into families and lifeforms to obtain sufficient non-zero data for treatment comparisons to be possible.

There was substantial variance heterogeneity and evidence of inconsistency among liketreated plots. Statistical analysis was based on the use of a linear, additive and apply repeatedmeasures analysis of variance (ANOVA) across the time periods for which observations are available, employing the Huynh-Feldt correction for serial correlation. To allow for possible violations in model assumptions, a conservative approach is taken in the interpretation of findings. Only where p-values are less than 0.01 are significant differences assumed, with p-values less than 0.001 assumed to identify strong evidence of differences. It is not judged appropriate to apply any pairwise comparison because the p-values are highly sensitive to model violation.

\section{Results}

For illustrative purposes, cover values of plant species are shown for different treatments over time (Figures 5, 6, 8). These cover values have been calculated by dividing the sum of cover percentages of a species in a set of quadrats by the number of quadrats in the set multiplied by 100 in order to standardise the cover estimates derived from variable numbers of quadrats.

\section{Climate of the study period}

During the study period (between 2003 and 2007), daily rainfall at the Bureau of Meteorology station at the Perisher Valley Ski Centre, $1712 \mathrm{~m}$, provided a reasonable estimate of precipitation at Pengillys Bog, which is $2.78 \mathrm{~km}$ to the north of the centre, at $1680 \mathrm{~m}$, and is the highest, wettest and most southerly site. Annual precipitation values for all years of the study were below the local average (1754 mm per annum), with 2008 recording the lowest annual rainfall $(1061 \mathrm{~mm})$ since the local station was established in 1976 (Figure 3). Since the fire, only 2005 recorded precipitation above $1500 \mathrm{~mm}$. Further, the period of study had the most consecutive years with below-average rainfall since records commenced, indicating a very dry period for the local area. The rainfall was predominantly received in spring and winter, with the spring months receiving the most. The temperature for the same period did not show any significant trends, although the mean maximum temperature for the summer months for 2003 and 2006 was three degrees above average (Bureau of Meteorology, 2009), which could have hindered the rate of Sphagnum recovery through bleaching. However, there is evidence that the temperature in the alpine areas in Australia has been increasing over the past 35 years (Hennessy et al. 2003).

Daily rainfall figures from automated gauges are available from the ACT mountains, and annual precipitation from Tom Gregory Bog, the lowest and driest study site, is also shown in Figure 3. Rainfall has been below the 1960-1990 mean (981 mm) since 1997 at this site, but the 2002-2003 pre-fire year was not as markedly dry as at Perisher. The other ACT sites track these results, with reasonable spring rain but dry, late summers occurring in most years. 


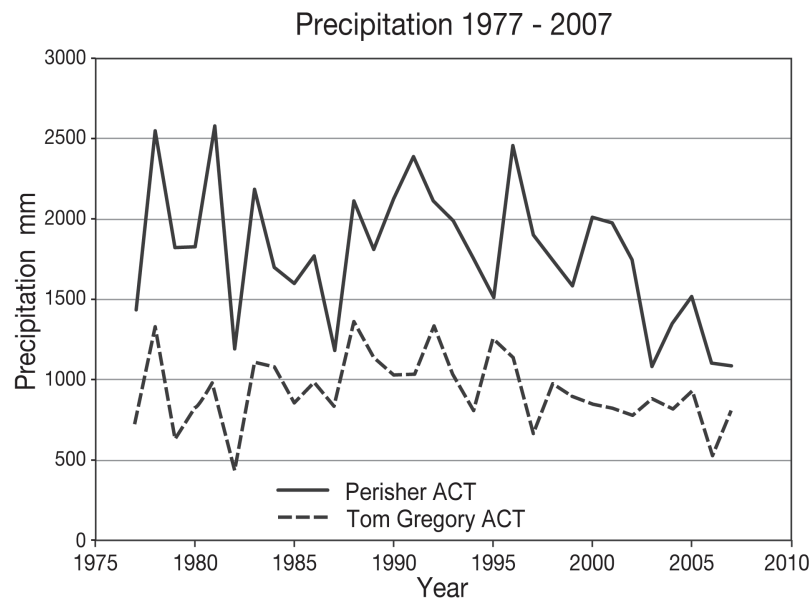

Figure 3. Annual precipitation (mm) 1977-2007 at the wettest site (Perisher Valley near Pengillys) and driest site (Tom Gregory, ACT). Long-term means are 1960-1990

\section{Vegetation response}

The data are characterised by the sparseness of presence of most taxa - of the 125 taxa recorded, only five taxa have more than $50 \%$ non-zero readings for at least one of the monitoring periods. Only by grouping taxa (families, lifeforms) is there sufficient data for meaningful analysis, and even after this grouping, there tends to be many zero readings. Figure 4 shows that mean floristic diversity (flowering plants, ferns and mosses) increased from three species/ quadrat after the fire to eight species/quadrat after 32 months, and has remained stable from 32 to 50 months.

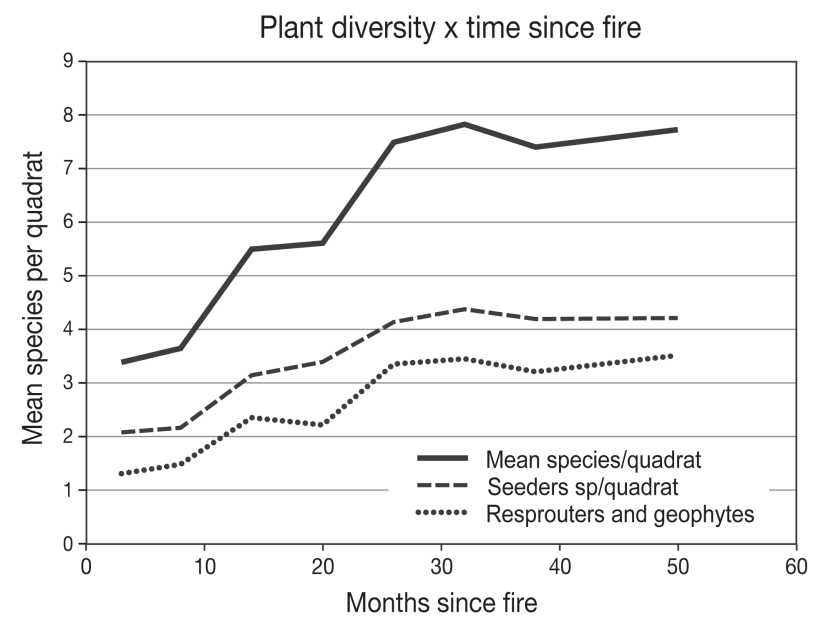

Figure 4. Floristic diversity change through time in mean species per quadrat for seeders and resprouters

Over four years, almost all quadrats recorded increases in cover due to both seed germination of grasses, sedges and epacrids and resprouting by Empodisma minus and myrtaceous shrubs. The ratio of resprouters to seeders has declined slightly over this time. Across all sites and treatments, the greatest number of post-fire observations of live taxa on our plots was of graminoids (32\% of observations) in autumn 2003, and they retained that dominance throughout the monitoring until autumn 2007 ( $96 \%$ of observations).

There is insufficient data to quantitatively analyse the benefits of the restoration techniques on the recovery of Sphagnum moss (predominantly S. cristatum). However, Sphagnum recovery does provide some broad indication of trends (Figure 5), with total Sphagnum cover in non- 
transplant plots under all other treatments increasing from $100 \mathrm{~m}^{2} /$ ha to $850 \mathrm{~m}^{2} / \mathrm{ha}$ after 32 months, and stabilising after this to 50 months.

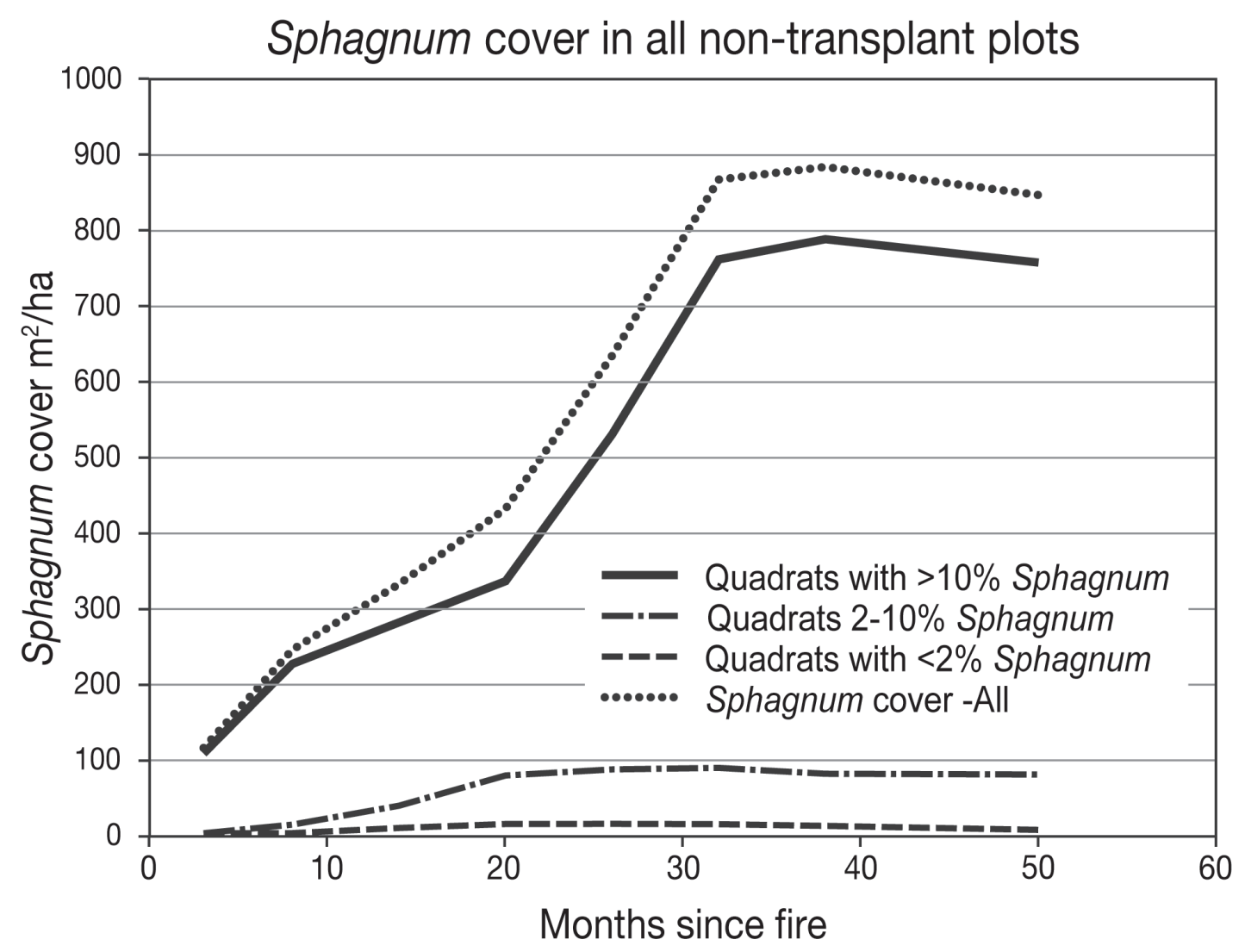

Figure 5. Total non-transplanted Sphagnum moss cover through time, shown as $\mathrm{m}^{2} /$ ha. The contribution of plots with $>10 \%$ and plots with $<2 \%$ is shown

Figure 5 shows that most Sphagnum regeneration occurs by the expansion of the larger patches (>10\% cover) of Sphagnum after 20 months. Many quadrats did not regenerate over 50 months, and low-cover patches $(<2 \%)$ did not always persist. At 20 months, some sheltered and moist sites showed signs of regeneration and recruitment of moss, but exposed burnt hummocks remained dead. The proportion of non-transplant quadrats containing live Sphagnum rose from $10 \%$ after the fire to $62 \%$ at 32 months and has since declined to $50 \%$ at 50 months. This may reflect continuing below-average rainfall at all sites.

There is no strong evidence that between-site variability in respect of changes in percentage cover is greater than within-site variability for any taxa or broader grouping that could be analysed $(p>0.01)$. Statistical analysis does indicate that the pattern and extent of recovery is dependent on the treatment or treatments employed for some taxa and broader (family and/or lifeform) groupings. Based on total percentage vegetation cover for all native species (not graphed here), there is evidence of treatment difference $(\mathrm{p}<0.001)$, with the earliest and most extensive recovery associated with horizontal shade cloth combined with the addition of fertiliser. This treatment favoured species that can resprout after fire when compared with species that are seed obligates. While different treatments have favoured different taxa, in general revegetation treatments that include the addition of fertiliser provide the fastest rate of recovery of vegetation cover. A range of taxa contributed to increases in vegetation cover, including Poa costiniana, other grasses, graminoids, bryophytes and shrubs. The combination of fertiliser and moss transplants had the greatest impact on the cover of Poa costiniana, however horizontal shade cloth alone provided for the greatest increase in the vegetation cover of Empodisma minus 
and Baloskion australe, while assisting the early establishment and regeneration of remnant Sphagnum plants. Straw mulch favoured only the Cyperaceous graminoids.

Figure 6 shows the response of Sphagnum to the shading treatments, with controls for comparison. Horizontal shade appears to maintain Sphagnum cover, in comparison with the small increases in cover values seen in the controls after 30 months.

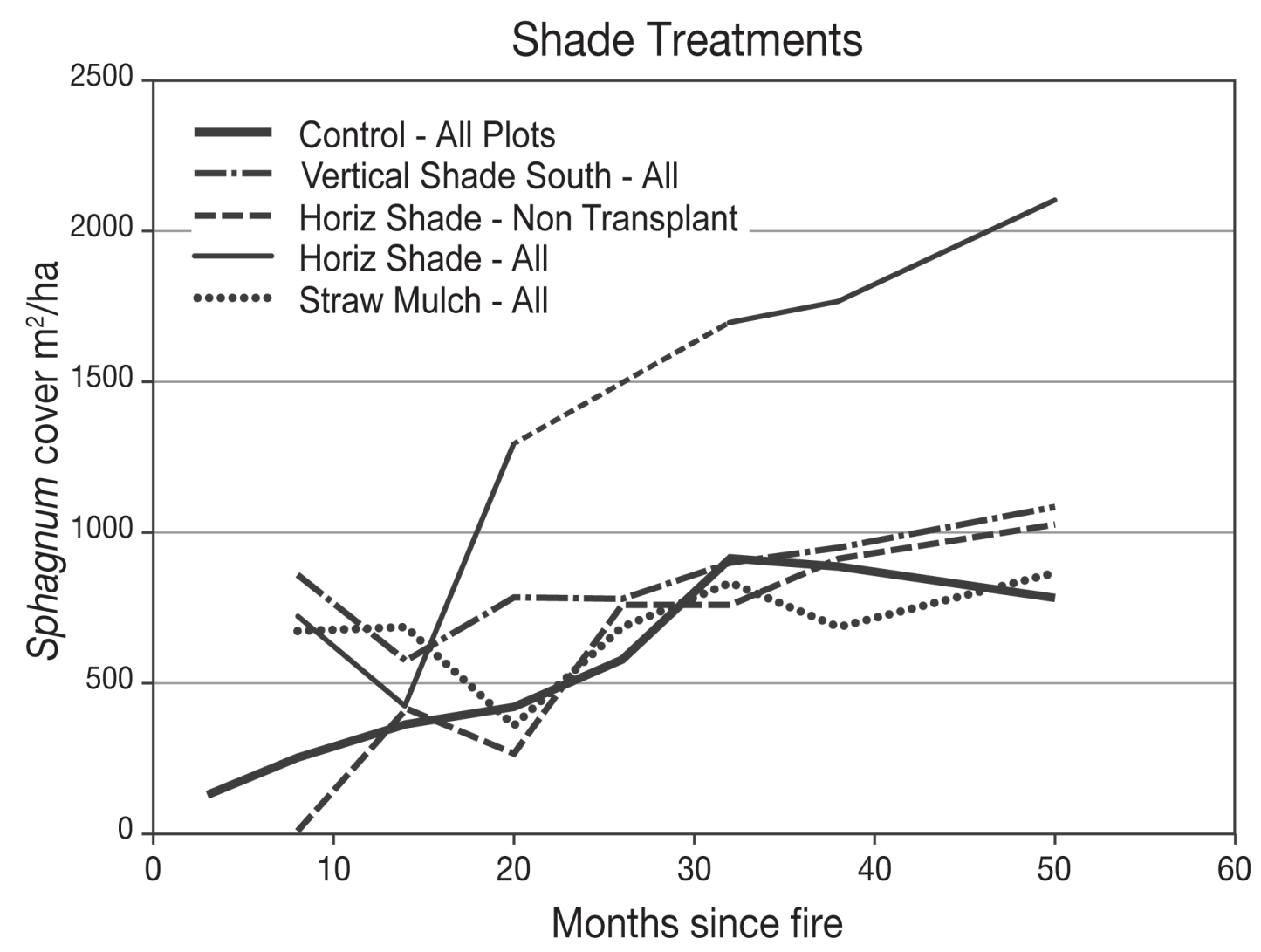

Figure 6. Comparison of treatments in terms of Sphagnum cover $\mathrm{m}^{2} /$ ha: 1 . Control, 2. Horizontal shade without transplants, 3. Mulch straw (no transplants), 4. Fertiliser, transplants and all shade treatments

Where plots were treated with horizontal shade cloth, there was good recruitment and the greatest expansion of transplants after 20 months. Both horizontal and vertical shade treatments showed declines in some transplant cover in the first six months, but then a continuous increase in cover to 50 months. When shade cloth was removed, the exposed vegetation was thicker, taller and greener than adjacent unshaded plots, but further measurements will reveal whether these effects persist over time (Figure 7, overleaf).

The assessment of the effects of all horizontal shade-cloth-only treatments on species cover combines Rotten Swamp and Pengillys Bog data for comparison with controls at these sites. When compared with unshaded plots, there is significant difference in recovery of all native plant species (percentage vegetation cover) treated with horizontal shade cloth over time $(\mathrm{p}=0.001)$, although forbs are the only lifeform that show significant increases in cover over time $(\mathrm{p}=0.005)$. Although the overall results from Rotten and Pengillys are similar, the data from Rotten Swamp are obtained from limited plot data and so results rely heavily on an assumption that the observations there are typical of the entire site. There was considerable inter-plot variability at Pengillys Bog, showing that not all shaded quadrats shared a positive response and that some unshaded quadrats recovered strongly on their own. Straw mulch, used only at Pengillys, had less effect than the controls, and had largely disappeared by 32 months and was undetectable at 50 months. Strong winds removed the mulch from some quadrats. 


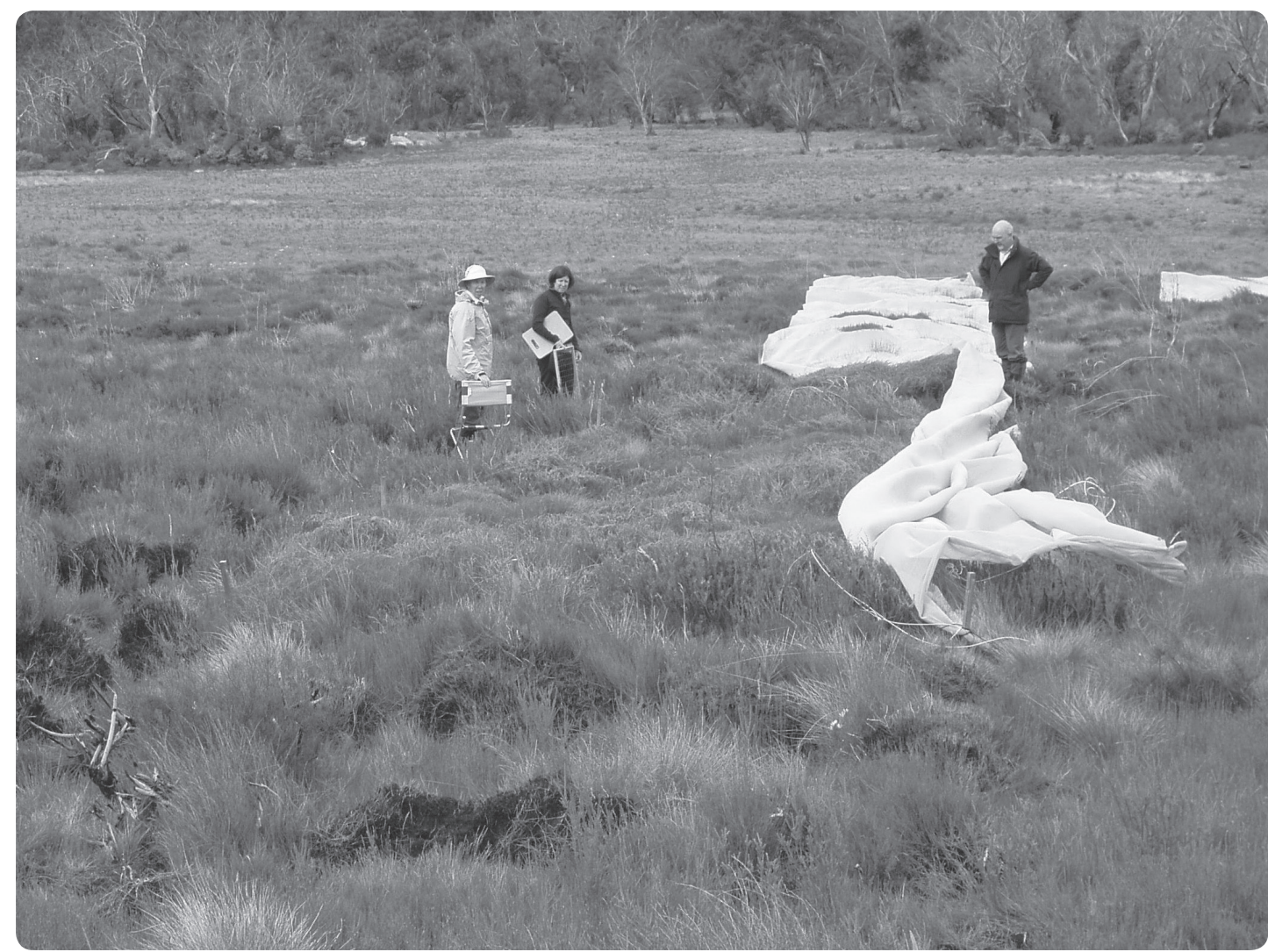

Figure 7. Shade cloth at Rotten Swamp removed for survey March 2007

The effects of fertiliser, transplants and shade on Sphagnum cover $\left(\mathrm{m}^{2} / \mathrm{ha}\right)$ are shown in Figure 8 (opposite). Low overall survival rates of the fist-sized transplants at Snowy Flat prevent a comparison of transplant-only and fertilised transplants. Only the larger transplants were successful, but all transplants at Tom Gregory and Pengillys received fertiliser.

For all fertilised plots, the continuing rise in moss cover after 32 months is largely due to moss expansion in quadrats with shade, but unshaded plots showed stable or declining cover. Hence, fertiliser on its own may not outperform the controls. However, fertiliser seems to support transplant growth, with most transplants also responding to shade. Analysis of plots that had no treatment applied showed there were no differences in cover of any species over time by site. However, when analysing changes in vegetation cover by only the time variable, Empodisma minus, Baloskion australe and Luzula sp. all showed significant increases in changes of percentage cover over time $(\mathrm{p}<0.01)$.

\section{Discussion}

In our study, tussock grasses (Poa spp.) and rhizomatous restiads (Empodisma minus and Baloskion australe) have rapidly regenerated from stools and underground rhizomes and they are replacing areas of dead Sphagnum moss. Shrubs of Baeckea gunniana and Callistemon sieberi were resprouting within 20 months, but epacrids, particularly Richea continentis, only started to appear in our plots after 20 months, suggesting that they will only regenerate from seed, as also noted by Keith (2002). In several plots, moss species, notably Polytrichum sp., are growing on burnt peat and dead Sphagnum cushions, a phenomenon noted in other burnt peatlands (Huber and Markgraf 2003).

Sphagnum regeneration has been shown to be complex and delayed. Long-term recovery to pre-fire Sphagnum cover will require significant colonisation and spread of Sphagnum beyond 


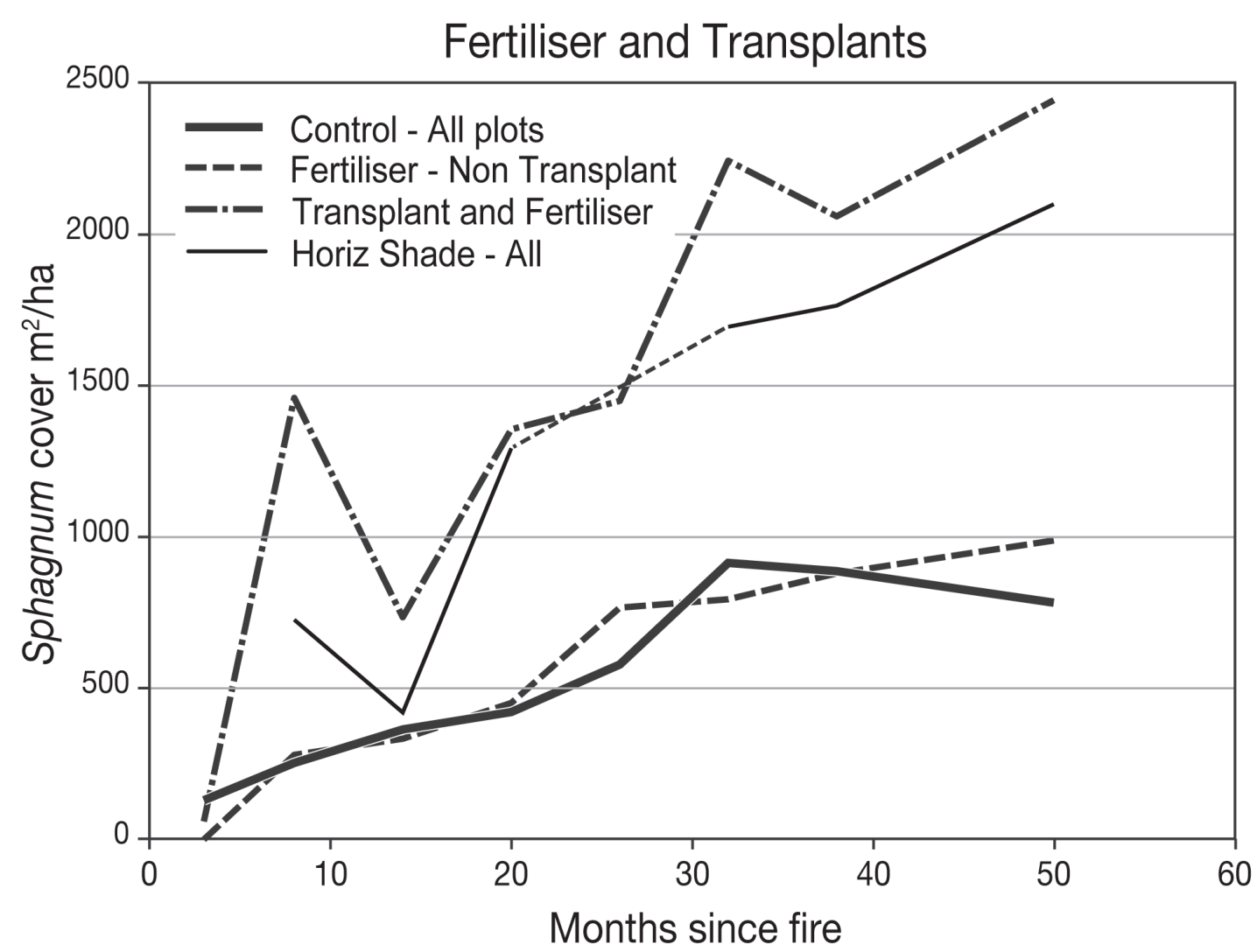

Figure 8. Effects of fertiliser and transplants on Sphagnum cover by comparison with controls. The quadrats include both shaded and non-shaded values. The initial steep rise is an artifact, as the earliest transplants were small and the larger transplants were not placed until month eight

the regeneration achieved in the first 32 months. Drought may in part explain the levelling out of the overall extent of Sphagnum cover after 32 months, but hummocks with shaded flanks and in moist shaded hollows have often continued to expand. These favourable micro-habitats seem to have enhanced survival and subsequent recovery of large patches of Sphagnum moss, in some cases not until more than 25 months after the fire. It is also clear that Sphagnum has not been able to regenerate on some plots. Such plots are typically severely burnt, or located on the exposed tops of dead hummocks, or located on drying sites where water flow has gone underground. However, after 18 months, many dead hummocks became crusted and hydrophobic and some had completely eroded down to hollow level by 50 months. These results indicate that very long recovery times are needed to restore Sphagnum bog structure. Hence, implementing a specific and appropriate fire-protection program for bogs and fens, particularly for high to very high intensity wildfires, may be necessary if long-term loss of bogs is to be avoided.

Peat where Sphagnum moss has been completely killed by the fire reached $\mathrm{pH}$ values of 5-7 shortly after the fire, but most moist sites returned to normal long-term values ( $\mathrm{pH} 4-4.5$ ) in the four years after the fire. The success rate of the large moss transplants at Tom Gregory is already less than $40 \%$ and it is recognised that site choice for transplants is critical, with shaded wet hollows offering the best chance for establishment and growth. The combination of transplants and fertiliser appears to be the most successful treatment at this time (2010). Ninety percent of the transplants at Pengillys Bog were successful in 2007, but site setting in wet hollows appeared to be more critical than any shade treatment. Figure 9 shows Empodisma expanding above a healthy transplant in a badly burnt plot with little other regeneration. In some transplants Sphagnum was outcompeted by tussock grasses or sedges that responded to fertiliser. These results show that transplants have some potential for re-establishing Sphagnum 
in areas from which it has been largely excluded, but are subject to a high rate of failure and probably not worthwhile where early natural recovery is observed.

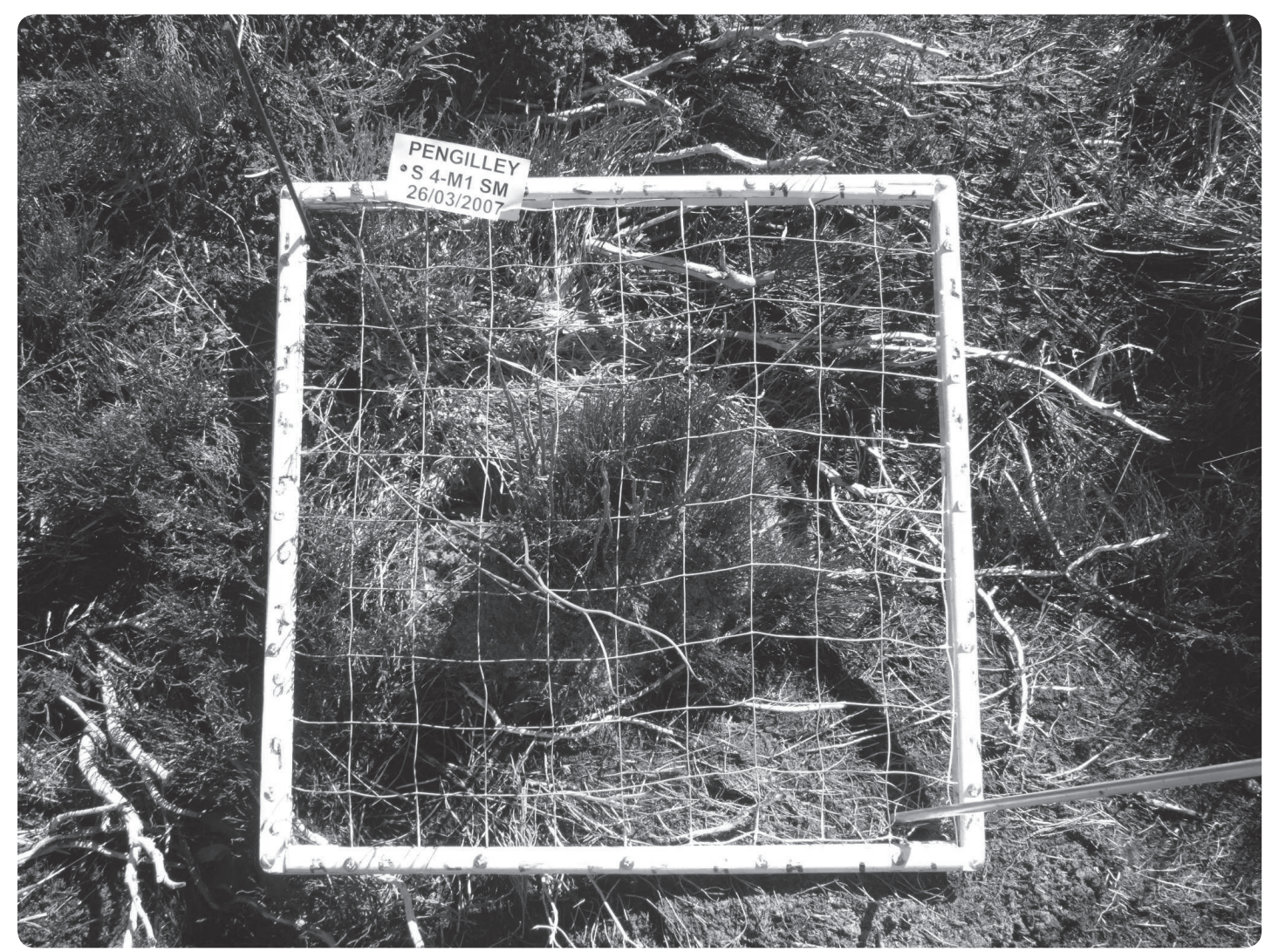

Figure 9. Successful Sphagnum transplant and fertiliser treatment in severely damaged area at Pengillys

Differences were observed between horizontal and vertical shading. The horizontal shade cloth and litter not only provided shade protection, but also reduced evaporation and wind movement over the burnt vegetation. The vertical shade cloth benefited species number, but only provided a benefit for a small area adjacent to the shade structure. Straw mulch was reasonably persistent after one year and effective in shielding moss hummocks, but after 12 months had packed down into mats, and after two to three years had decomposed. Neither shade treatment seems to be effective in encouraging moss development when compared with controls (Figure 6). However, shading had beneficial effects for most other lifeforms, with vegetation under shade cloth observed to have increased vigour and growth when compared with unshaded plots. Straw commonly has been used in restoration projects as a protective mulch and was initially used in these trials. However, the difficulty of transport and effective spreading of the straw at the required rate make it difficult to use in large field restoration programs. The use of shade cloth was found to be a suitable alternative and is now recommended, as it provided a uniform $70 \%$ shade cover and could be readily rolled out over large areas, or laid out by slinging under a helicopter.

Recent field rehabilitation and restoration work (post 2003 fires) in the NSW and Victorian alps (Good 2006; Good et al. In press) and the field experiments reported here indicate the importance of shading for Sphagnum growth and recovery. Shrubs (Epacris spp. Baeckea gunniana and Richea continentis) and taller herbs (Empodisma minus and Baloskion australe) provide shading in stable natural mires. Sphagnum regenerates very slowly, if at all, after severe burning of Sphagnum hummocks, but artificial shading provides the critical level of protection from solar radiation (high UV levels) and wind desiccation for any surviving plants, and a considerable enhancement of the rate of regeneration of Sphagnum. From the 
results of this study, Empodisma minus has also benefited from artificial shading, but is not dependent on it for survival and regeneration.

While there were a significant number of weed species recorded post fire, none of the treatments appears to have differentially favoured the weeds, although some plots have become dominated by weed species, such as Acetosella vulgaris, Cirsium vulgare, Holcus lanatus, Hypochaeris radicata and Taraxacum officinal. These are largely the most damaged plots where surface peats were burnt. The enhancement of Sphagnum regeneration and its water-retention capacity is likely to minimise colonisation of the fire-damaged bogs and fens by particular weed species. Dead Sphagnum and the drying of the underlying peat potentially provide a suitable environment for active colonisation by weeds and native herbaceous species from the surrounding grasslands. Our data, and observations post fire, indicate that bog and fen ecosystems can be readily transformed to grassland if the ecosystem dries out, indicating the importance of ensuring appropriate moisture/water regimes are maintained or recovered.

The trials sought to establish the potential and value of early intervention to accelerate the natural succession to mature Sphagnum-shrub bogs. It is still too early to fully quantify the value of artificial shading, transplants and fertiliser applications to the regeneration of bog communities. Although considerably altered from the pre-disturbance state, regeneration of damaged bog and fen vegetation is possible, and can be enhanced by rehabilitation techniques, such as the addition of fertiliser and the provision of shading. Transplants may have a limited role in some cases. Our experimental and monitoring programs aim to support the choice of techniques that will enhance regeneration and guide future management of these peatlands.

This analysis after only four years indicates that bog and fen vegetation, particularly the significant and functionally important Sphagnum, can be enhanced in its rate of recovery, thus shortening the long regeneration time of bog and fen ecosystems that would occur under 'natural' regeneration. The restoration of the water-retention capacity and the functional hydrological role of the underlying peats is an extremely long process (up to 30 years). The implementation of vegetation restoration techniques is only the starting point to full recovery of these systems, which will require sensitive ecologically based management for many years. Remeasurement of plots in the future will allow the longer-term efficacy of the trials to be assessed more fully.

Bogs and fens have a fundamental role in catchment hydrology in the Alps and should be maintained in a condition that ensures catchment stability, water yield, water quality and stream flow regimes. This is likely to become an even greater management issue as the importance of bogs and fens for catchment management becomes clearer, with climate-change predictions - including increases in bushfire intensity and occurrence - for the Alps being realised in the next decade or two (Zylstra 2008).

\section{Acknowledgements}

This paper is dedicated to the memory of our friend and colleague Amanda Carey, who was an energetic, professional and cheerful advocate for the conservation and restoration of montane peatlands. We thank Brett MacNamara and Dave Whitfield, Namadgi National Park, ACT; Murray Evans, ACT Parks Conservation and Lands; Ken Green, NSW NPWS; and Colin de Paget, Alan Wade and Bren Weatherstone for their active encouragement and help. Trish McDonald, ACT Parks Conservation and Lands, assisted with most of the fieldwork and data analyses and provided cheerful project support. The analyses would not have been possible without the understanding, determination and resolve of our biometrician, Glen McPherson. The research monitoring was supported by Parks Conservation and Lands (ACT TAMS), the Australian National University, the Biodiversity Conservation Branch (Tasmanian DPIW), Namadgi National Park and the NSW National Parks and Wildlife Service. Shading, replanting 
and water spreading measures have been put in place by Namadgi and Kosciuszko National Parks staff as part of the post-2003 fire catchment rehabilitation program, with the welcome assistance of numerous park-care volunteers. This paper has been improved by addressing the comments of an anonymous referee.

\section{References}

Ashton, D.H. and G.R. Hargreaves 1993. Dynamics of subalpine vegetation at Echo Flat, Lake Mountain, Victoria. Australian Journal of Ecology 12:35-60.

Carr, S.G.M. and J.S. Turner 1959. The ecology of the Bogong High Plains, II. Fencing experiments in grassland. Australian Journal of Botany 7:34-63.

Clark, R.L. 1980. Sphagnum growth on Ginini Flats. Canberra: ACT Report to NSW National Parks and Wildlife Service.

Clarke, P.J. and A.R.H. Martin 1999. Sphagnum peatlands of Kosciuszko National Park in relation to altitude, time and disturbance. Australian Journal of Botany 47:519-536.

Cobbaert, D., L. Rochefort and J.S. Price 2004. Experimental restoration of a fen plant community after peat mining. Applied Vegetation Science 7:209-220.

Costin, A.B., D.J., Wimbush, D. Kerr and L.W. Gay 1959. Catchment hydrology in the Australian Alps 1. Div. Plant Industry CSIRO Technical Paper N013, pp36. Canberra: CSIRO.

Good, R.B. 1976. Contrived regeneration of alpine herbfields. Paper presented to the ANZAAS Congress, Hobart, Tasmania. pp8.

Good, R.B. 1992. Kosciusko Heritage - The conservation significance of Kosciusko National Park. Sydney: National Parks and Wildlife Service and Surrey Beatty \& Sons.

Good, R.B. 2000. Rehabilitation and revegetation of the Kosciuszko summit area: an historic review. In J. Mill (ed.) Proceedings of the Third Australian Network for Plant Conservation Annual Conference, pp12-20. Albury: Australian Network for Plant Conservation.

Good, R.B. 2004. Rehabilitating fire-damaged wetlands in the Snowy Mountains. Australasian Plant Conservation 12:3-4.

Good, R.B. 2006. Post-fire ecosystem rehabilitation in Namadgi and Kosciuszko National Parks. In K. McCue, S. Lenz and S. Friedrich (eds) Caring for Namadgi, Science and People, () pp121-128. Canberra: National Parks Assoc (ACT).

Good, R.B., G. Wright, J. Whinam and G. Hope 2010. Restoration of mires of the Australian Alps following the 2003 wildfires. In S.G. Haberle, J. Stevenson and M. Prebble (eds), Altered Ecologies: Fire, Climate and Human Influence on Terrestrial Landscapes, pp353-362 Terra Australis 32. The Australian National University, Canberra: ANU E-Press.

Hennessy, K., P. Whetton, I. Smith, J. Bathols, M. Hutchinson and J. Sharples 2003. The impact of climate change on snow conditions in mainland Australia. Melbourne: CSIRO Atmospheric Research.

Hope, G.S. 2003. The mountain mires of southern New South Wales and the Australian Capital Territory: their history and future. In J. Mackay and Assoc. (eds) Celebrating Mountains. Proceedings of an International Year of the Mountains Conference, pp67-79. Jindabyne: Australian Alps Liason Committee.

Hope, G.S., J. Whinam and R. Good 2005. Methods and preliminary results of post-fire experimental trials of restoration techniques in the peatlands of Namadgi (ACT) and Kosciuszko National Parks (NSW). Ecological Management and Restoration 6:215-218.

Huber, U.M. and V. Markgraf 2003. European impact on fire regimes and vegetation dynamics at the steppe-forest ecotone of southern Patagonia. The Holocene 13:567-579. 
Johnston, S.W. and R.B. Good 1996. The impacts of exogenous Zinc on the soils and plant communities of Carruthers Peak, Kosciuszko National Park NSW. Proceedings of ASSSI and NZSSS National Soils Conference, Melbourne. 3:117-118.

Keith, D. 2002. Population dynamics of an endangered heathland shrub, Epacris stuartii (Epacridaceae). Recruitment, establishment and survival. Austral Ecology 28:67-76.

Lintermans, M. and W. Osborne 2002. Wet and Wild; a Field Guide to the Freshwater Animals of the Southern Tablelands and High Country of the ACT and NSW. Canberra: Environment ACT.

McDougall, K. and N. Walsh 2007. Treeless vegetation of the Australian Alps. Cunninghamia 10(1):1-57.

Rochefort, L., F. Quinty, S. Campeau, K. Johnson and T. Malterer 2003. North American approach to the restoration of Sphagnum dominated peatlands. Wetlands Ecology and Management 11:3-20.

Wahren, C-H.A. and N.G. Walsh 2000. Impact of fire in treeless sub-alpine vegetation at $\mathrm{Mt}$ Buffalo National Park, 1982-1999. Report to the Australian Alps Liaison Committee.

Wahren, C-H.A., R.J. Williams and W.A. Papst 1996. The ecology of wetlands and snow patches on the Bogong High Plains. Melbourne: Unpublished report to Australian Heritage Commission and Dept of Natural Resources and Environment.

Walsh, N.G. and K.L. McDougall 2004. Progress in the recovery of the flora of treeless subalpine vegetation in Kosciuszko National Park after the 2003 fires. Cunninghamia $8: 439-452$.

Whinam, J. 1990. A study of the ecology of Tasmanian Sphagnum peatlands. Ph.D. thesis, University of Tasmania, Australia.

Whinam, J. 1995. Effects of fire on Tasmanian Sphagnum peatlands. Bushfire '95. Australian Bushfire Conference 27-30 September 1995, presented papers 133pp.

Whinam, J. and R. Buxton 1997. Sphagnum peatlands of Australasia: an assessment of harvesting sustainability. Biological Conservation 82:21-29.

Whinam, J. and N. Chilcott 2002. Floristic description and environmental relationships of Sphagnum communities in NSW and the ACT and their conservation management. Cunninghamia 7:463-500.

Whinam, J., G.S. Hope, P. Adam, B.R. Clarkson, P.A. Alspach and R.P. Buxton 2003. Sphagnum peatlands of Australasia: the resource, its utilisation and management. Wetlands Ecology and Management 11:37-49.

Wimbush, D.J. and A.B. Costin 1979. Trends in vegetation at Kosciuszko. I. Grazing trials in the subalpine zone, 1957-1971. Australian Journal of Botany 27:741-787.

Zylstra, P. 2008. Climate change, forest flammability and strategic management options in Kosciuszko National Park. In K. McCue and S. Lenz (eds) Corridors for Survival in a Changing World, pp9-20. Canberra: National Parks Assoc. ACT. 